\title{
Hubungan antara Aqidah dan Akhlak dalam Islam
}

\author{
Alnida Azty, Fitriah, Lufita Sari Sitorus, Muhammad Sidik, Muhammad Arizki, Mohd. \\ Najmi Adlani Siregar, Nur Aisyah Siregar, Rahayu Budianti, Sodri \& Ira Suryani* \\ Program Magister Pendidikan Agama Islam Fakultas Ilmu Tarbiyah dan Keguruan \\ Universitas Islam Negeri Sumatera Utara, Indonesia
}

Diterima: Desember 2018; Disetujui: Desember 2018; Dipublish: Desember 2018

E-mail: irasuryani@uinsu.ac.id

\begin{abstract}
Abstrak
Artikel ini membahas mengenai hubungan antara aqidah dan akhlak dalam ajaran Islam. Aqidah sebagai sistem kepercayaan yang bermuatan elemen-elemen dasar keyakinan, menggambarkan sumber dan hakikat keberadaan agama. Sedangkan akhlak sebagai sistem etika menggambarkan arah dan tujuan yang hendak dicapai agama. Akhlak dalam pandangan Islam harus berpijak pada keimanan. Iman tidak cukup hanya disimpan dalam hati, namun harus dipraktikkan dalam kehidupan sehari-hari dalam bentuk akhlak yang baik. Aqidah erat hubungannya dengan akhlak, karena akhlak tersarikan dari aqidah dan pancaran dirinya. Oleh karena itu jika seorang beraqidah dengan benar, maka akhlaknya pun akan benar, baik dan lurus. Begitu pula sebaliknya, jika aqidah salah, maka akhlaknya pun akan salah.
\end{abstract}

Kata Kunci: Aqidah, Akhlak, Islam.

\begin{abstract}
This article discusses the relationship between aqidah and morals in Islamic teachings. Aqidah as a belief system that contains the basic elements of belief, describes the source and nature of the existence of religion. Whereas morality as an ethical system describes the direction and purpose of religion. Morals in the view of Islam must rest on faith. Faith is not enough to only be kept in the heart, but it must be practiced in daily life in the form of good morals. Aqidah is closely related to morals, because morals are extracted from aqidah and emanation of themselves. Therefore if a person is a true believer, then his character will be right, good and straight. Vice versa, if aqidah is wrong, then the morals will be wrong.

Keywords: Aqidah, Morals, Islam.

How to Cite: Alnida, A. Fitriah. Sitorus, L.S.. Sidik, M. Arizki, M. Siregar, M.N.A. Siregar, N.A. Budianti, R. Sodri. Suryani, I. (2018). Hubungan antara Aqidah dan Akhlak dalam Islam. Journal of Education, Humaniora and Social Sciences (JEHSS). 1 (2): 122-121.
\end{abstract}

\section{PENDAHULUAN}

Kehadiran agama Islam yang dibawa oleh Nabi Muhammad SAW diyakini dapat menjamin terwujudnya kehidupan manusia yang sejahtera lahir dan batin. Petunjuk-petunjuk agama mengenai berbagai kehidupan manusia, sebagaimana terdapat di dalam sumber ajarannya, $\mathrm{Al}-$ Quran dan Hadits, tampak amat ideal dan agung. Sedangkan akal pikiran sebagai alat untuk memahami Al-Quran dan Hadits. Ketentuan ini sesuai dengan agama Islam itu sendiri sebagai wahyu yang berasal dari Allah SWT. Hal demikian dinyatakan dalam Al-Quran Surah An-Nisa' ayat 59 yang berbunyi: "Hai orang-orang yang beriman, taatilah Allah dan taatilah Rasul (Nya), dan ulil amri di antara kamu. kemudian jika kamu berlainan pendapat tentang sesuatu, maka kembalikanlah ia kepada Allah (Al-Quran) dan Rasul (sunnahnya), jika kamu benar-benar beriman kepada Allah dan hari kemudian. yang demikian itu lebih utama (bagimu) dan lebih baik akibatnya" (QS. An-Nisa': 59).

Aqidah sebagai sistem kepercayaan yang bermuatan elemen-elemen dasar keyakinan, menggambarkan sumber dan hakikat keberadaan agama. Sedangkan akhlak sebagai sistem etika menggambarkan arah dan tujuan yang hendak dicapai agama. Muslim yang baik adalah yang 
memiliki aqidah yang lurus dan kuat yang mendorongnya untuk melaksanakan syariat yang hanya ditujukan kepada Allah sehingga tergambar kesalehan akhlak yang terpuji pada dirinya. Aqidah, syariat dan akhlak dalam Al-Quran disebut iman dan amal shaleh. Iman menunjukkan makna aqidah, sedangkan amal shaleh menunjukkan pengertian akhlak (Supadie, dkk, 2015).

\section{PEMBAHASAN Aqidah}

Menurut bahasa, kata Aqidah berasal dari bahasa Arab yang berakar dari kata 'aqadaya'qidu-'aqdan-'aqidatan. 'Aqdan berarti simpulan, ikatan perjanjian dan kokoh, setelah terbentuk menjadi aqidah berarti keyakinan (Sinaga, dkk, 2017). Menurut Haroen, aqidah yang berasal dari 'aqada berarti mengikat, membuhul, menyimpulkan, mengokohkan atau menjanjikan. Pengertian ini juga diperkuat oleh Yunahar Ilyas, beliau menyatakan bahwa aqidah adalah keyakinan yang tersimpul kokoh di dalam hati, bersifat mengikat dan mengandung perjanjian (Imran, 2017). Dari beberapa pendapat di atas, maka aqidah adalah keyakinan yang dianut oleh setiap manusia terhadap sesuatu hal yang menjadi dasar aktivitas dan pandangan hidupnya.

Aqidah Islam adalah sesuatu yang bersifat tauqifi, artinya suatu ajaran yang hanya dapat ditetapkan dengan adanya dalil dari Allah dan Rasul-Nya. Maka, sumber ajaran aqidah Islam adalah terbatas pada Al-Quran dan Sunnah saja. Karena, tidak ada yang lebih tahu tentang Allah kecuali Allah itu sendiri, dan tidak ada yang lebih tahu tentang Allah, setelah Allah sendiri, kecuali Rasulullah SAW. Namun, sebagian ulama menambahkan ijma' sebagai sumber ajaran Islam ketiga setelah Al-Quran dan Sunnah.

Penjelasan dari sumber-sumber aqidah akhlak yaitu sebagai berikut:

\section{a. Al-Quran}

Menurut bahasa Al-Quran memiliki arti bacaan. Menurut istilah Al-Quran adalah wahyu Allah yang diturunkan kepada Nabi Muhammad SAW secara lisan, makna, dan gaya bahasa (ushlub) yang termaktub dalam mushaf yang dinukil darinya secara mutawatir (Amudidin, dkk, 2006). Al-Quran adalah kalam Allah yang hakiki, diturunkan kepada Rasulullah dari Lauh Mahfuz melalui malaikat Jibril dengan proses wahyu, yang berfungsi sebagai pedoman bagi umat manusia.

Jadi, dapat disimpulkan bahwa pengertian Al-Quran adalah perkataan (kalam) Allah yang hakiki, diturunkan kepada Rasulullah SAW dengan proses wahyu, membacanya termasuk ibadah, disampaikan kepada kita dengan jalan mutawatir (jumlah orang yang banyak dan tidak mungkin bersepakat untuk berbohong), dan terjaga dari penyimpangan, perubahan, penambahan dan pengurangan.

b. Sunnah

Sunnah menurut bahasa Arab, adalah ath-thariqah, yang berarti metode, kebiasaan, perjalanan hidup, atau perilaku. Kata tersebut berasal dari kata as-sunan yang bersinonim dengan ath-thariq (yang berarti jalan). Mengikuti sunnah berarti mengikuti cara Rasullulah bersikap, bertindak, berfikir dan memutuskan (Amudidin, dkk, 2006).

Sunnah (sering disebut juga dengan Hadits), merupakan segala tingkah laku Nabi Muhammad SAW baik berupa perkataan, perbuatan, maupun ketetapan (taqrir). Sunnah merupakan sumber hukum Islam yang kedua setelah Al-Quran. Allah SWT telah mewajibkan untuk menaati hukum-hukum dan perbuatan-perbuatan yang disampaikan oleh Nabi Muhammad SAW.

c. Ijma'

Ijma' dalam pengertian bahasa yaitu upaya (tekad) terhadap sesuatu. Sedangkan menurut istilah, ijma' berarti sumber aqidah yang berasal dari kesepakatan para mujtahid umat Muhammad SAW setelah beliau wafat, tentang urusan pada suatu masa (Rohman, et.al., 2007). Mereka bukanlah orang yang sekedar tahu tentang masalah ilmu tetapi juga memahami dan mengamalkan ilmu. 
Berkaitan dengan ijma', Allah SWT. berfirman: "Dan barangsiapa yang menentang Rasul sesudah jelas kebenaran baginya, dan mengikuti jalan yang bukan jalan orang-orang mukmin, kami biarkan ia leluasa terhadap kesesatan yang telah dikuasainya itu dan kami masukkan ia ke dalam Jahannam, dan Jahannam itu seburuk-buruk tempat kembali" (QS. An-Nisa': 115).

Aqidah merupakan suatu keyakinan hidup yang dimiliki oleh manusia. Keyakinan hidup ini diperlukan manusia sebagai pedoman hidup untuk mengarahkan tujuan hidupnya sebagai mahluk alam. Pedoman hidup ini dijadikan pula sebagai pondasi dari seluruh bangunan aktivitas manusia atau yang disebut juga dengan akhlak.

\section{Akhlak}

Kata Akhlak (akhlaq) berasal dari bahasa arab, merupakan bentuk jama' dari "khuluq" yang menurut bahasa berarti budi pekerti, perangai, tingkah laku, atau tabiat. Kata tersebut mengandung persegi persesuaian dengan kata "khalq" yang berarti kejadian (Supadie dan Sarjuni, 2012). Ibnu 'Athir dalam Didiek, menjelaskan bahwa khuluq itu artinya gambaran batin manusia yang sebenarnya (yaitu jiwa dan sifat-sifat bathiniah), sedang khalq merupakan gambaran bentuk jasmaninya (raut muka, warna kulit, tinggi rendah badan, dan lain sebagainya) (Supadie, 2015). Maka akhlak bisa dikatakan sistem etika yang menggambarkan dan tujuan yang hendak dicapai agama. Kata khulq merupakan bentuk tunggal dari akhlak, tercantum dalam Al-Quran surah Al-Qalam ayat 4: "Sesungguhnya engkau (Muhammad) berada di atas budi pekerti yang agung." (QS. Al-Qalam: 4)

Secara terminologi terdapat beberapa definisi akhlak yang dikemukakan para ahli, diantaranya Ahmad Amin mendefinisikan akhlak sebagai kehendak yang dibiasakan (Amin, 2005). Hal ini sejalan dengan pengertian akhlak yang diungkapkan oleh Imam Al-Ghazali yang mendefinisikan akhlak sebagai sifat yang tertanam dalam jiwa yang menimbulkan perbuatanperbuatan dengan mudah tanpa memerlukan pemikiran dan pertimbangan (al-Ghazali, Tth). Kemudian dipertegas lagi Ibnu Miskawih, beliau menyatakan bahwa akhlak merupakan suatu hal atau situasi kejiwaan yang mendorong seseorang melakukan suatu perbuatan dengan senang tanpa berfikir dan perencanaan (Maskawaih, th).

Akhlak menduduki peran penting dalam kehidupan manusia, diantaranya menjadi standar nilai bagi suatu bangsa dan menjadi tolok ukur nilai pribadi bagi seseorang (Nasharuddin, 2007). Islam memandang akhlak itu sangat penting untuk mewujudkan kedamaian dan keselamatan manusia di dunia dan akhirat. Itu sebabnya Nabi Muhammad SAW diutus untuk memperbaiki akhlak manusia sehingga tercipta ketentraman, sebagaimana firman Allah SWT dalam Surah AlAhzab ayat 21 yang berbunyi: "Sesungguhnya telah ada pada (diri) Rasulullah itu suri tauladan yang baik bagimu (yaitu) bagi orang yang mengharap (rahmat) Allah dan (kedatangan) hari kiamat dan dia banyak menyebut Allah". (QS. Al-Ahzab: 21)

Ayat tersebut memberikan petunjuk bahwa Nabi Muhammad SAW adalah suri tauladan hidup bagi orang-orang yang beriman, bagi mereka yang sempat bertemu langsung dengan Rasulullah SAW, maka cara meneladani Rasulullah dapat mereka lakukan secara langsung. Sedangkan bagi mereka yang tidak sezaman dengan Rasulullah SAW, maka cara meneladani Rasulullah SAW adalah dengan mempelajari, memahami dan mengikuti berbagai petunjuk yang termuat dalam sunnah atau Hadits beliau (Ismail, 2007).

\section{Hubungan Aqidah dengan Akhlak}

Aqidah adalah gudang akhlak yang kokoh. Ia mampu menciptakan kesadaran diri bagi manusia untuk berpegang teguh kepada norma dan nilai-nilai akhlak yang luhur. Akhlak mendapatkan perhatian istimewa dalam aqidah Islam. Rasulullah SAW bersabda yang artinya: "Aku diutus untuk menyempurnakan akhlak yang mulia" (HR. Ahmad dan al-Baihaqi).

Islam menggabungkan antara agama yang hak dan akhlak. Menurut teori ini, agama menganjurkan setiap individu untuk berakhlak mulia dan menjadikannya sebagai kewajiban (taklif) di atas pundaknya yang dapat mendatangkan pahala atau siksa baginya. Atas dasar ini agama tidak mengutarakan akhlak semata tanpa dibebani rasa tanggung jawab. Bahkan agama 
menganggap akhlak sebagai penyempurna ajaran-ajarannya karena agama tersusun dari keyakinan (aqidah) dan perilaku.

Oleh karena itu akhlak dalam pandangan Islam harus berpijak pada keimanan. Iman tidak cukup hanya disimpan dalam hati, namun harus dipraktikkan dalam kehidupan sehari-hari dalam bentuk akhlak yang baik. Dengan kata lain bahwa untuk mempergunakan dan menjalankan bagian aqidah dan ibadah, perlu pula berpegang kuat dan teguh dalam mewujudkan bagian lain yang disebut dengan bagian akhlak. Sejarah risalah ketuhanan dalam seluruh prosesnya telah membuktikan bahwa kebahagiaan di segenap lapangan kehidupan hanya diperoleh dengan menempuh budi pekerti (berakhlak mulia).

Hasbi Ash Shiddieqy di dalam bukunya Al Islam mengatakan bahwa kepercayaan dan Budi pekerti dalam pandangan Al-Quran hampir dihukum satu, dihukum setaraf, sederajat. Lantaran demikianlah Tuhan mencurahkan kehormatan kepada akhlak dan membesarkan kedudukannya. Bahkan Allah memerintahkan seorang muslim memelihara akhlaknya dengan kata-kata perintah yang pasti, terang, dan jelas. Para muslim tidak dibenarkan sedikit juga menyia-nyiakan akhlaknya, bahkan tak boleh memudah-mudahkannya (Shiddieqy, tth).

Aqidah tanpa akhlak adalah seumpama sebatang pohon yang tidak dapat dijadikan tempat berlindung di saat kepanasan dan tidak pula ada buahnya yang dapat dipetik. Sebaliknya akhlak tanpa aqidah hanya merupakan layang-layang bagi benda yang tidak tetap, yang selalu bergerak. Oleh karena itu Islam memberikan perhatian yang serius terhadap pendidikan akhlak. Rasulullah SAW menegaskan bahwa kesempurnaan iman seseorang terletak pada kesempurnaan dan kebaikan akhlaknya. Sabda beliau: "Orang mukmin yang paling sempurna imannya ialah mereka yang paling bagus akhlaknya". (HR. Muslim)

Dengan demikian, untuk melihat kuat atau lemahnya iman dapat diketahui melalui tingkah laku (akhlak) seseorang, karena tingkah laku tersebut merupakan perwujudan dari imannya yang ada di dalam hati. Jika perbuatannya baik, pertanda ia mempunyai iman yang kuat; dan jika perbuatan buruk, maka dapat dikatakan ia mempunyai iman yang lemah. Dengan kata lain bahwa iman yang kuat mewujudkan akhlak yang baik dan mulia, sedang iman yang lemah mewujudkan akhlak yang jahat dan buruk.

Nabi Muhammad SAW telah menjelaskan bahwa iman yang kuat itu akan melahirkan perangai yang mulia dan rusaknya akhlak berpangkal dari lemahnya iman. Orang yang berperangai tidak baik dikatakan oleh Nabi sebagi orang yang kehilangan iman. Beliau bersabda: "Malu dan iman itu keduanya bergandengan, jika hilang salah satunya, maka hilang pula yang lain". (HR. Hakim)

Kalau diperhatikan hadits di atas, nyatalah bahwa rasa malu sangat berpautan dengan iman hingga boleh dikatakan bahwa tiap orang yang beriman pastilah ia mempunyai rasa malu; dan jika ia tidak mempunyai rasa malu, berarti tidak beriman atau lemah imannya.

Aqidah erat hubungannya dengan akhlak. Aqidah merupakan landasan dan dasar pijakan untuk semua perbuatan. Akhlak adalah segenap perbuatan baik dari seorang mukalaf, baik hubungannya dengan Allah, sesama manusia, maupun lingkungan hidupnya. Berbagai amal perbuatan tersebut akan memiliki nilai ibadah dan terkontrol dari berbagai penyimpangan jika diimbangi dengan keyakinan aqidah yang kuat. Oleh sebab itu, keduanya tidak dapat dipisahkan, seperti halnya antara jiwa dan raga.

Hal ini dipertegas oleh Allah SWT dalam Al-Quran, yang mengemukakan bahwa orangorang yang beriman yang melakukan berbagai amal shaleh akan memperoleh imbalan pahala disisi-Nya. Dia akan dimasukkan ke dalam surga Firdaus. Penegasan ini dikemukakan dalam firman Allah SWT. sebagai berikut: "Sesungguhnya orang-orang yang beriman dan beramal saleh, bagi mereka adalah surga Firdaus menjadi tempat tinggal, Mereka kekal di dalamnya, mereka tidak ingin berpindah dari padanya" (QS. Al-Kahfi: 107-108).

Ayat di atas memperlihatkan betapa pentingnya aqidah dan akhlak, dengan keterpaduan keduanya seseorang akan memperoleh pahala yang besar disisi Allah dengan jaminan surga Firdaus. Hubungan antara aqidah dan akhlak ini tercermin dalam pernyataan Nabi Muhammad 
SAW yang diriwayatkan dari Abu Hurairah yang artinya: "Dari Abu Hurairah r.a., Rasulullah SAW. bersabda, 'orang mukmin yang sempurna imannya ialah yang terbaik budi pekertinya'”.

Dasar pendidikan akhlak bagi seorang muslim adalah aqidah yang benar, karena akhlak tersarikan dari aqidah dan pancaran dirinya. Oleh karena itu jika seorang beraqidah dengan benar, niscaya akhlaknya pun akan benar, baik dan lurus. Begitu pula sebaliknya, jika aqidah salah maka akhlaknya pun akan salah.

Dengan akhlak yang baik seseorang akan bisa memperkuat aqidah dan bisa menjalankan ibadah dengan baik dan benar, dengan itu ia akan mampu mengimplementasikan tauhid ke dalam akhlak yang mulia (akhlaqul karimah).

Hubungan manusia dengan Allah SWT dan kelakuannya terhadap Allah SWT ditentukan dengan mengikut nilai-nilai aqidah yang ditetapkan. Karena barangsiapa mengetahui Sang Penciptanya dengan benar, niscaya ia akan dengan mudah berperilaku baik sebagaimana perintah Allah. Sehingga ia tidak mungkin menjauh atau bahkan meninggalkan perilaku-perilaku yang telah ditetapkan-Nya.

\section{SIMPULAN}

Aqidah erat hubungannya dengan akhlak. Aqidah merupakan landasan dan dasar pijakan untuk semua perbuatan. Akhlak adalah segenap perbuatan baik dari seorang mukalaf, baik hubungannya dengan Allah, sesama manusia, maupun lingkungan hidupnya. Berbagai amal perbuatan tersebut akan memiliki nilai ibadah dan terkontrol dari berbagai penyimpangan jika diimbangi dengan keyakinan aqidah yang kuat. Oleh sebab itu, keduanya tidak dapat dipisahkan, seperti halnya antara jiwa dan raga.

\section{DAFTAR PUSTAKA}

Abdullah, Y. (2007). Studi Akhlak dalam Persepektif Al-Quran. Jakarta: Amzah Al-Ghazali, I. (tth). Ihya' 'Ulum ad-Din. Beirut: Dar Ihya' al-Kutub al-Islamiyah. Alim, M. (2006). Pendidikan Agama Islam. Bandung: P.T. Remaja Rosda Karya. Amin, A. (2005). Etika (Ilmu Akhlak). Jakarta: Bulan Bintang. Amudidin, dkk. (2006). Pendidikan Agama Islam. Jakarta: Graha Ilmu. Anwar, R. (2008). Akidah Akhlak. Bandung: Pustaka Setia. Ash-Shiddieqy, H. (tth). Al Islam. Beirut: Dar Ihya' al-Kutub al-Islamiyah. Ilyas, Y. (2004). Kuliah Akidah Islam. Yogyakarta: LPPI. Ismail, M.S. (2007). Metodologi Penelitian Hadits Nabi. Jakarta: Bulan Bintang. Kementerian Agama RI. (2012). Al-Quran dan Terjemahan New Cordova. Bandung: Syaamil Qur'an. Maskawaih, I. (tth). Tahzib al-Akhlak. Beirut: Dar Ihya' al-Kutub al-Islamiyah. Nasharuddin. (2015). Akhlak: Ciri Manusia Paripurna. (Jakarta: Raja Grafindo Persada. Pasha, M.K. (2003). Aqidah Islam. Jogjakarta: Citra Karsa Mandiri. Rohman, R.A. (2007). Akidah dan Akhlak. Bengkulu: Tiga Serangkai. Saebani, B.A. (2005). Ilmu akhlak. Bandung: Pustaka Setia. Supadie, D.A. (2015). Studi Islam II. Jakarta: Raja Grafindo Persada. Supadie, D.A. dkk. (2012) Pengantar Studi Islam. Jakarta: Raja Grafindo Persada. 